\title{
Reasons to Be Cheerful: Thinking Sustainably in a (Climate) Changing World
}

Kersty Hobson*

Department of Human Geography, Research School of Pacific and Asian Studies, Australian National University

\begin{abstract}
Although some still claim them as purely technological and economic concerns, climate change and sustainability present profound challenges to all levels of practice, from international governance institutions to domestic day-to-day habits. This diagnosis has become increasingly emphasised in environmental governance debates, which raises questions about how we all might engage with and think about making changes to these often highly charged spheres of practice, to encourage environmental and socially sustainability. In this article, I draw on recent experiences of a sustainable living workshop in Adelaide, Australia, to discuss how insights from participants' views on appropriate models of social change particularly the perspective of one 'street philosopher' - along with human geographical environmental governance research, and aspects of gestalt theory can together suggest a positive and creative research praxis: one that works to draw out subjects (and our own) stories and aspirations to 'think sustainably'.
\end{abstract}

\section{Introduction}

Anyone who has considered, for even a brief time, the challenges future climate change presents to us all will probably struggle to disagree with Tol et al.'s (2004, 263) assertion that 'although all the problems of the world are reflected in climate change, one should not try and solve all these problems with climate policy'. Some - mostly found on the right of the political spectrum - do still maintain climate change is an issue for economists and scientists alone. Salvation thus lies in more accurate economic and climate models, the geo-sequestration of carbon dioxide, and nuclear energy: or at least that has been the case here in Australia (see Hamilton 2007). In contrast, many others from all over the political and religious spectrum argue that the causes of climate change and our responses to it touch upon every aspect of how we do and should live and inter-relate to each other and our environments. In short, climate change is as much about ethics and justice as it is about sound science, sustainable economic growth and technological fixes. Or as Parks and Roberts $(2006,337)$ put it: 
[I]ts political resolution requires addressing stark inequality and injustice: in who will suffer the most, its effects, in who created the problem in the first place, and in who is taking action to address the problem.

Part of the resolution Park and Roberts elude to concerns the day-to-day choices we all make, about how to live and consume. It also concerns the machinations of national politics and international relations, which - if exemplified by the ebbs and flows of the Kyoto Protocol - are neither constructed nor negotiated on a level playing field (for example, see Najam et al. 2003). For instance, increases in greenhouse gas emissions to date have been caused chiefly by industrialised societies such as the USA, although China is soon set to attain the dubious honour of the world's highest absolute (not per capita) emitter. Yet, it is poorer, low-lying nations such as Bangladesh and Pacific island nations that will feel the impact most acutely and very soon, with little capacity for the rapid social and economic adaptation required for material and cultural survival (see Mimura 1999; Thomas and Twyman 2005). Some have even argued this makes climate change 'an act of aggression by the rich against the poor', as Uganda's president Yoweri Museveni bluntly put it (The Associated Press 2007).

Add to all of the above the recently presented and quite frankly grim future impact scenarios of the Intergovernmental Panel on Climate Change (Intergovernmental Panel on Climate Change Working Group II 2007), and the title of this article may appear rather deluded. That is, given all the above, what reasons are there to be cheerful? There are some pretty obvious responses to this question. We all have the capacity to do something about climate change, such as altering our consumption practices at home and work. We can take part in some form of activism that advocates non-governmental organisation, party political or grassroots action. An increasing array of celebrities of varying hues are publicly voicing their concerns about the future with talk of deep cuts in greenhouse gas emissions - once the refrain of only the radical and/or far-sighted - now the talk of much mainstream debate (rarely the place of the radical and/or far-sighted). While such shifts do not necessarily represent a new Zeitgeist, they do give some cause for optimism. However, my aim here is not to argue that hope and cheer can only result from a positive reading of these shifts: after all, as the lateral and creative thinking proponent Edward de Bono has pointed out, positive thinking and constructive thinking are not the same thing (de Bono 1999). Rather, I aim to argue here that 'being cheerful' is a fundamental prerequisite to conducting research into pathways to a healthy and sustainable future.

This is a tack Elizabeth Shove and Gordon Walker recently adopted in a 2007 Environment and Planning $A$ editorial. Here, they posed a question I am sure many of us will have pondered. That is:

In a manifestly complex world, dominated by hegemonic ideologies of neoliberal capitalism, global finance and commodity flows is it really possible to intervene 
and deliberately shift technologies, practices and social arrangements . . . onto an altogether different, altogether more sustainable track? (Shove and Walker 2007, 763)

They think it is, and so do I. But how? In this article, I want to discuss one possible way to explore this question. I argue that the fundamentally ethical nature of how we think about and respond to climate change offers a potentially fertile and creative area of engagement with this topic. This does not necessitate that we all must become more ethical. Nor does it suggest an abstract environmental moral philosophy be constructed and then rolled out into practice (Darier 1999; Varela 1999). Rather, my argument has its foundations in ongoing human geographical debates about the lived and embodied nature of 'everyday ethics' (e.g. Barnett et al. 2005): ethics that concern not only our own domestic practices but also our roles as tertiary researchers and educators (e.g. Cloke 2002; Lynn 2003; Massey 2004; Mitchell 2004; Popke 2006).

The relevance of such conceptual debates will become clearer, as I draw on recent personal experience of a sustainable living workshop in Adelaide, South Australia. In the process of creating recommendations to go forward to South Australia's sustainable consumption strategy, this workshop explored the diverse modes of engagement that might engender widespread pro-environmental behaviour changes in Adelaide and beyond. And in here lies the key to my argument. As expected, we discussed at length the mainstay models of social change: that is, the 'top-down government-first' and the 'bottom-up change-individual-behaviour-first' approaches. In addition, workshop participants advocated a more ad hoc, opportunistic mode of engagement. Such an approach swerves from adherence to a set of pre-defined sustainable development best-practice guidelines. Instead, it fosters broad engagements with diverse and collective concerns about current and future well-being, echoing a question Richard Le Heron $(2006,441)$ has posed.

What might flow from thinking sustainably, rather than thinking about sustainability? What issues are likely to surface as such a re-think is progressed? (Author's own italics)

In this article, I aim to take Le Heron's questions seriously and explore some issues that do surface when one attempts to think sustainably, especially if sustainable thinking is conceptualised and researched as a form of praxis that is fundamentally ethical. In doing so, I draw together human geographers work on environmental governance; an (all too brief) engagement with gestalt psycho-analytical theory; the Aristotelian concept of Phronesis; and the work of one 'street philosopher'. This may seem like a rather eclectic combination to address the sobre issues of climate change and sustainability but, in part, that is the point. As Albert Einstein (a man always good for a pithy quote) is alleged to have commented, we are not going to solve problems using the same logic that gave rise to the 
problems in the first place - a sentiment I suggest mirrors the fundamental challenge of trying to 'think sustainably'.

\section{Aligning 'Already Existing Sustainabilities' and Human Geographical Research}

In March 2007, I attended a 1-day workshop in Adelaide on sustainable consumption and living, at the invitation of the Chair of the South Australia Premier's Round Table on Sustainability. This workshop brought together individuals from state government, civic groups, small business and education whose professional practices touch on issues of living and consuming sustainably. The ultimate purpose of the workshop was to draw together policy recommendations around sustainable consumption to be taken forward to the South Australia Premier.

As one often is at such events, I was very much impressed by the passion, commitment and innovative thinking in the room. The day presented an opportunity for me - thinking and writing around the issue of sustainable consumption as I have done for a decade now - to meet with and learn more about the diverse and creative work being undertaken by institutions and individuals in South Australia. That is, to find out more about 'already existing sustainabilities' (Krueger and Agyeman 2005) in and around Adelaide; that is, the institutions and practices that may not fit neatly under a pro-environmental or ecological umbrella but all the same are grounded in a praxis of positive social change and low ecological impact.

As well as being impressed, I was also struck during the day by a lingering frustration among participants. For the most part, this was centred on the slow pace of change taking place, despite earnest and prolonged attempts to alter entrenched patterns of thought and behaviour within government, business and the home. Thus, as you might expect, one key area of debate during the workshop was about which methods and institutions are best equipped to forge positive social change. That is, how can we encourage individuals and institutions to behave more sustainably? And where should the impetus for this change come from? If opinion polls are to be believed, the simple answer to the last question is the 'government' (e.g. Climate Institute 2007). Thankfully, workshop participants were more than aware of the complexities of this question, as the modes of social change aired were deemed contingent on the contours of the issue at hand and its political and social context.

Despite these different perspectives and experiences, what did become clear during the day was a definite alignment between recent human geographical research and the practices of some policy, non-governmental organisations and small business participants. For one, both argue that profound ethical and empirical flaws negate the policy proclamations that the consumer and the consumer alone bear ultimate responsibility for greening consumption and overall sustainability. Qualitative social science research has shown that the 'consumer as sovereign' approach - prevalent 
in many pro-environmental behaviour change campaigns - assumes marketbased preference aggregation is the most feasible pathway to sustainability (see Darier 1996; Hobson 2006). For example, exhortations to 'save money while helping the environment' assumes all are open to seamless shifts in opinions and behaviours (see Hinchliffe 1997; Slocum 2004). However, as Burkitt (2002, 226) has put it:

People can [also] be taught the reasons, the practical wisdom, of acting virtuously, yet it would seem that this in itself is not enough to make a person virtuous.

Indeed, while entreaties to 'do your bit' can have some (albeit often minor) positive outcomes (e.g. Hobson 2003), they also promote a very particular form of environmental responsibility that can close-off other pathways of engagement. That is, the environment becomes a thing 'out there' to feel guilty and responsible about, and/or obliged towards: a feeling that can only be ameliorated by installing energy-saving light bulbs and putting the recycling out once a week, thus de-emphasizing the political and collective nature of sustainability challenges (Hobson 2006).

Does this mean then a 'top-down government-first' approach is right after all? Well, yes and no. During the Adelaide workshop, it was apparent that states and other policy actors rolling out clear top-down agendas is still a valid approach in some instances. Again, the tenor of these discussions had strong resonance with human geographical research, particularly work that focuses on multiscalar pathways and sites of governance, environmental or otherwise. Here, politics with a small ' $p$ ' (governance, in its broadest sense) and a capital 'P' (formal and party politics; see Flint 2003) means politicians, institutions and states are no longer privileged as the main focus of action and analysis (see Bulkeley 2005). Instead, the agency of all actors is highlighted, which underscores the importance of working with less formal spaces and modes of social action (for example, see Bakker and Bridge 2006).

\section{How We Do Change? Start from Where We Are. . .}

How then do these debates about social change discussed in the Adelaide workshop resonate with the above? Some attendees articulated their vision of sustainability governance strategies as - instead of a language of structures or individualised responsibility - one of opportunism, spontaneity and multiple spaces. This suggests a form of policy and praxis entrepreneurship - or 'out of the box' thinking - that holistic sustainability advocates support. For example, there was talk of being plugged into 'untapped markets for change' through particular 'pressure points' at specific 'moments'. On the one hand, it could be argued that this language reflects the interpersonal networks that already characterise contemporary governance practices (Bulkeley 2005). Or, it can also be argued that it underscores the penetration of market-based logics into policy arenas. Both these points 
are certainly fair comment, and are open to further debate. However, I want to argue here that such modes of working do evoke Le Heron's challenge of 'thinking sustainably'. That is, they require we do more than just factor in pre-defined sustainability principles through the endless production of sustainable development reports; the setting up of committees that remain balkanized within bureaucratic structures; and indeed, the seemingly inexhaustible analysis of divergent definitions of sustainable development and their material outcomes - a practice that even former UK prime minister Tony Blair grew tired of, declaring: 'We have spent a long time getting to grips with the concept of sustainability. I want to declare a moratorium on further words' (Her Majesty's Government, UK 2005, 4).

So, without further wrangling over what sustainable development means, how do we act? Being open to the specific 'pressure points' that Adelaide workshop attendees (and indeed others, for example, Shove and Walker 2007) have underlined suggests sustainability - in its broadest definition - must first exist as a core concept or underlying motive. The challenge then is how to make it as such. During the Adelaide workshop, some participants argued that this process begins with a 'start from where we are' agenda. One example of what this might mean in practice was drawn from the UK Sustainable Consumption Roundtable's (2006) 'I will if you will' report, which, among other things, outlined the need to work with and not against people's aspirations. That is, in terms of altering individual lifestyles, decades of evidence now shows that preaching and hectoring us all is not a positive or sustainable approach. Instead, messages and practices have to work with, not against, our hopes and ideals of well-being.

While certainly respectful of what various speakers had to say, my gut reaction was to be mildly suspicious of this argument. It seemed to suggest a form of 'weak' sustainability (Chatterton 2002) that echoes a 'business as usual' wherein current trajectories of growth and consumption are not disrupted to achieve sustainable outcomes. Thus, factoring in 'aspirations' is possibly pandering to the current glut of material (and one with Marxist leanings would say, false) needs and wants, and does little to question the fundamental values that underpin consumerism and a lack of regard for the environment.

Not that it is hard to see how such an agenda gains credence in the pragmatic policy world. Climate change scenarios and their ameliorative pathways are often framed and experienced as a lack, a sacrifice, a going without that no one really wants to endure (for example, see Princen et al. 2002). It is also hard for us, whether poor or rich, to imagine the potentially profound changes ahead without feeling overwhelmed and despondent at the potential breakdown of our ways of life: or as Lear $(2006,83)$ sanguinely puts it, 'this inability to conceive of its own devastation will tend to be the blind spot of any culture.' Thus, to avoid feelings of helplessness of disengagement, we are now encouraged to turn our lights off for $1 \mathrm{hr}$ to observe 'Earth Hour'; ${ }^{1}$ or to watch on television others trying to live 
sustainably, as in the six-part Australian documentaries Eco House and Carbon Cops; or to purchase a book in the popular '. . . for Dummies' titles on 'Sustainable Living'. These moves can be argued as clever marketing ploys, to make sustainability the 'latest thing': but are they in themselves sustainable? Does the marketisation of the environment tinker at the margins (Shove 2003) and re-entrench the identities of a self-interested consumer? While I could present an analysis that takes the rest of this article to offer a resounding 'yes' to this question, during the Adelaide workshop and since then I have found my scepticism and assumptions challenged, in terms of the possibilities within a 'start from where people are' agenda. That is, is there something more interesting (and even radical) here with more potential and depth than appears at first glance?

\section{. . . But to Start from Where We Are We First Have to Know Where We Are At}

To explain a key debate to date in both policy and some academic writing has been around the existence of a 'value-action' gap (see Burgess et al. 2003). This gap is said to exist as, even if many of us do hold pro-environmental values, they often remain unexpressed in practice due to internal and external barriers. Here, the role of policy is to both alter values, making them more pro-environmental, as well as removing barriers through, for example, public education, access to 'green' goods and infrastructure alterations. Then, behaviour change will ensue (see Hobson 2001). While there is no doubt some credence in this model - especially in terms of changes to infrastructure (Shove 2003) - the assumptions that we all hold coherent values that follow linear trajectories of thought to action, brain to body have been roundly critiqued by philosophers, sociologists, some psychologists and human geographers (e.g. Butler 1997; Ernste 2004; Whatmore 2002). Instead, it is argued that to be human is to be replete with diverse, fluctuating and often-contradictory thoughts and beliefs, which are enacted with, take shape in, and are expressed at different times, in different contexts. Indeed, while some writers have keenly constructed categories of value types in relation to the environment - for example, eco-centric and anthropocentric (O’Neill 1997; Stern 1992) - psychologists have shown that such 'environmental values' can only explain $10 \%$ of variance in behaviour (Bamberg 2003). That is, what one claims to care about does not strongly determine how one behaves. Therefore, for me, in trying to think about what issues arise as we start to think sustainably as Le Heron suggests, one that emerges is how then do we start from 'where people are' if we are not clear where this is, if there is no road map to the human psyche?

Enter David Engwicht, a keynote speaker at the Adelaide workshop. David is a self-proclaimed and self-employed 'street philosopher' whose creative approaches to addressing 'traffic nuisance' in USA and Australian suburbs has created institutions such as the Walking School Bus, along 
with other positive strategies that aim to empower individuals and groups to reinvest in their local communities. For example, rather than advocate the installation of yet more speed bumps or roundabouts to deal with speeding traffic, David facilitates various techniques that encourage neighbours to reclaim their streets as a space of habitation and encounter. David claims:

The speed on most streets is determined to a large extent by the degree to which the residents have psychologically retreated from their street. (Engwicht 2005, 11)

The solution then is to halt this psychological retreat, to stop viewing streets as dangerous places now the domain of the car, and to reinvest them with sociality - an approach that has produced positive outcomes for the communities David has worked with many times over.

While David spoke at the Adelaide workshop about his ideas and experiences, the parallels between his work and those of some human geographers were too strong to ignore. Coming from outside the academy, David's work is not based on any particular school of philosophy per se but rather emerges from inadvertent and unplanned (by his own accounts) observations of how households re-inhabiting their street space engender slower car speeds and greater civic engagement. In the next and final section of this article, I want to expand on these parallels. The aim here is not just to outline what amazing coincidences they suggest: nor to posit the possibility of triangulation they offer for our own theories (although both of these are certainly true). Rather, I want to suggest how we might employ and take forward, both theoretically and in practice, some of David's insights in conjunction with our own - giving credit and space for knowledge generated outside the academy (Whatmore 2006) that can move researchers towards 'thinking sustainably'.

\section{One Approach to Starting From Where We Are: Or the Creative Play of Already Existing Ethics}

Now, I come full circle to the opening assertion of this article: that is, the challenges of climate change and sustainability are fundamentally ethical ones. For the most part, ethics is understood as a philosophical exploration of the right principles for action, often framed as abstract principles that can and should move from thought to practice. For others, the emphasis is on the practical nature of ethics: that is, it is about doing and being rather than a thing of itself. Some take their cue from Aristotle who argued that out of the three intellectual virtues - Episteme (scientific, universal knowledge), Techne (craft/art) and Phronesis (ethics, praxis) - the latter alone refers to deliberations on right behaviour. However, Phronesis is not an abstract body of knowledge. Rather, it is pragmatic, contextdependent and, most importantly, indivisible from practice (Flyvbjerg 2001). Human geographers have made similar claims. For example, recent research 
argues that seemingly 'ethical' or 'green' consumption practices (e.g. buying Fair Trade goods) do not originate from or exist within a sphere of thought and action set apart from the other, more mundane practices of the everyday. Rather, they are extensions of already existing 'ordinarily ethical' modes of being, which are the basis from which a myriad of conscious daily decisions are made (see Barnett et al. 2005; Clarke et al. 2007). If for the moment we take this argument as credible, the question then becomes not so much who is ethical, as environmental psychologists or market researchers might ask. Rather, it is how such ordinary ethics are appealed to and articulate with specific policies such as those aimed at forging pro-environmental or ethical consumption practices (Barnett et al. 2005). From here, we can then ask how a 'starting from where we are' approach might connect with our already existing ethical dispositions. That is, as we already have the capacity to think sustainably, how can these ethics be activated in ways that appeal to aspirations to live a life of collective well-being?

To think more on this question, I return again to David Engwicht. In his book Mental Speed Bumps: The Smarter Way to Tame Traffic (2005), Engwicht talks about the social constitution of space, primarily through the lens of urban design. Here, Engwicht argues neighbourhoods can be places of positive engagement when created and utilised as spaces of spontaneous exchange - again, echoing work from within the academy (for example, see Massey 2005). Positive (sustainable, in its broadest conception) living thus emerges from what he calls the 'borderlands': that is, spaces that bring together different trajectories of action and thought. In these spaces, no one story or ideology holds sway, for example, 'this road is for cars only' or 'I can only cross the road at a pedestrian crossing'. Instead, ambiguities are built into urban use-function such as blurring the boundaries between road and pavement. This can work to slow cars down, for example, as it makes users engage - so Engwicht claims - with the inherent paradoxes of how we move through and think about public spaces.

Such paradoxes concern not only the different functions for one structure (e.g. the multiple uses for roads and parks). They also refer to the paradoxes and multiple identities within all of us, which shift depending on context, mood, etc. The move then is to forge positive engagements with the ethics of collective well-being by constructing spaces that play on and with our inherent paradoxes and multiple subject positions, to prevent one story of what matters in our lives today from dominating, crowding out and shutting down other parts of ourselves. For example, in a space where the car no longer is king, mobility can become about more than just getting from A to B (e.g. meeting new people).

This argument certainly aligns with findings from research into behaviour change campaigns, not least of all my own (e.g. Hobson 2003). For example, I have suggested that if only our 'consumer' sensibilities are engaged through pro-environmental campaigns, the parts of ourselves that care about shared responsibility and social justice can become outraged, which 
in turn may prove counterproductive in terms of promoting sustainable consumption. Thus, for Engwicht, the trick is not to berate ('bad consumer', 'bad citizen') or talk only to the dominant narrative ('this'll save you money!') but to positively and creatively appeal to other stories, to other selves that articulate with already existing ethics. For example, instead of telling us all not to drive cars for the obvious reasons - 'peak oil', pollution, obesity, safety, noise - we can appeal to the part of all of us that loves the outdoors, wants interaction and small adventures on the way to work and school, and resents being at the mercy of multinational oil companies and dubious foreign policy decisions.

So here then (at last!) is a reason to be cheerful. That is, 'starting from where people are' does not have to be considered a cop-out for those of us who want a more extensive and inclusive form of social change than a 'business as usual' agenda suggests. Rather, it may be a sustainable way to engage both ourselves as researchers, and our research subjects as cocreators of sustainable futures - in short, to think sustainably. Thus, our aspirations - understood as dreams, hopes and goals that pertain to more than just individual material concerns - along with Phronesis-based praxis are already replete with visions and/or desires of collective and personal well-being. As David Engwicht's work shows, it is when these visions and dreams are articulated within supportive and constructive contexts that they connect with the challenges of sustainability, avoiding feelings of being overwhelmed or preached at. Of course, the implications of this argument for theory and practice require much further exploration and support. There is only limited space here to undertake such a task, but I begin briefly by suggesting one body of theory that may bolster and help develop further such lines of argument.

\section{The Paradoxical Theory of Change and Experimental Research Praxis}

Human geographers have over the years engaged with many permutations of psychoanalytical theory, mostly within the 'third wave' of psychological epistemologies. In keeping with the 'cultural turn' within human geography, these theories are founded on positive and humanistic views of the subject (see Burgess 1999; Sibley 2003; Valentine 1999). One such school of thought is gestalt theory. Gestalt is a broad (and often conflicting) body of work and I can offer here only a brief foray into one of its permutations.

At its core, the founders of gestalt therapy, such as Frederick Perls, sought to move away from previous psychotherapy practices, especially Freudian-based analysis, that proffered re-exploration of the individuals past and buried memories - often explored whilst lying on 'the couch' as the way to sound mental health. Instead, Perls and others argued that only by connecting with what we feel, here and how, can we discover and dispense with the actual neurosis that drives us (e.g. Perls 1969). Thus, gestaltists argue for positive change as a process of mutual and personal 
discovery: one that does not rely on the interpretations of the therapists, as this creates a constant cycle of top dog/under dog (i.e. 'that's not what I said/meant' or 'that's not quite what I meant but you're the expert'). The aim is also to stop the 'fitting game', where new information the client unearths about themselves is quickly slotted into existing storylines about who they are.

In placing an emphasis on the here and now - not only in the therapeutic situation but also in life in general - gestalt therapy has obvious parallels with, and overtly draws on Eastern philosophies, such as Buddhism. But what are the actual mechanisms by which gestalt therapy can bring about positive change? One mechanism, which I argue has potential alignments with a 'start from where we are' agenda and David Engwicht's work, is Arnold Beisser's 'paradoxical theory of change' (see Beisser 1970). Beisser claimed that positive change can occur within a person - not as an isolated individual but one embedded in social institutions and collectivities - when one becomes truly what one is, not when one tries to become what one is not. That is, positive change is not about obtaining or instilling a new set of ethics or addressing public ignorance with information campaigns. Rather, it comes from fully investing in one's current position. That is, we can 'start from where we are', to open up and explore the parts of us that want to live differently - the already ethical parts of us that are open to and already do think sustainably.

Note, I am definitely not arguing here that we all must now embark on years of (expensive) gestalt therapy. Nor do I want to try and wilfully play around with individuals' minds, as there is definite room for harm in such moves (see Burgess 1999). My aim here is rather to suggest one way to (empirically and ethically) ground the idea of thinking sustainably, if we have dispensed or at least added other strategies to the 'value-action' gap and 'blame those with more (perceived) power than ourselves' models of working: both as a governance approach and as an academic story about how the world is. This then is not just an argument about mobilising a specific body of theories as explanatory tools - it also pertains to our own practices as researchers.

For example, in recent years, focus group research has been utilised extensively to gain insight into lay perceptions of pollution, science, sustainable consumption and environmentalism, to name just a few topics. While I do not wish to dismiss the findings from this research outright, I do wonder - especially given the gestaltian and David Engwicht's arguments discussed above - whether the practice of putting a group of (often) strangers in a room for $1 \mathrm{hr}$ simply engages the 'letting off steam' and 'finger pointing' part of ourselves, which is often then presented in journal articles and conference papers as a slice of 'how it is'. Of course, human geographers employ a range of qualitative methodologies, including action research and in-depth discussion groups, some of which draw heavily on various psychotherapeutic traditions (for example, see Burgess et al. 1988; 
Pain 2003). Yet, there is disquiet that an inherent conservatism exists within our methodological tool-box, which allows access to only a limited range of social practices and knowledges. For example, Sarah Whatmore $(2006,606)$ has commented there is an:

$[\mathrm{U}]$ rgent need to supplement the familiar repertoire of humanist methods that rely on generating talk and text with experimental practices that amplify other sensory, bodily and affective registers.

Along similar lines, gestalt practitioners argue that, to explore the here and now, therapy subjects and therapists alike need to get up off the couch and take part in experimental "methodological techniques and skills to promote... and encourage growth' (Starak et al. 1994, 20), such as visualisation and body work.

As such, there is a nascent alignment between human geography, gestalt practice and the street philosophy of David Engwicht. That is, if we can argue that nobody needs to be taught to think sustainably per se - that is, the aspirations to live a low-impact and full life already exist - then, the playful and creative work of Whatmore's, Engwicht's and gestaltists 'experimental practices' suggests innovative methodological approaches be employed. Not that such an agenda is without substantial challenges. Contemporary funding structures and end-user imperatives, along with our own institutional ambits and career progressions, can make these ways of working difficult at best. My aim here has not been programmatic per se but rather to use the space this article has afforded as a chance to explore one possible epistemological and methodological pathway towards thinking sustainably.

\section{Concluding Remarks: Sustainable Development Is Dead, Long Live (Thinking) Sustainability!}

Given the unprecedented nature of predicted social and biophysical climate change impacts, many writers argue that entrenched ways of thinking about possible policy pathways (e.g. technological fixes, information campaigns) no longer suffice. This is, of course, easier said than done, especially in light of the inertia of extant institutions, infrastructures and personal habits. However, this does not mean that we therefore stop searching for provocative ways to think through such challenges. This has added impetus if we believe, as I and many others do (e.g. Flyvbjerg 2001) that critical social science researchers are in a clear and morally sound position to be part of positive social change.

While academic research practices can be considered one institution to facilitate positive sustainability praxis, are there others? Some argue that 'scaling-up' pathways of change is the best solution. For example, a global environmental organisation with the same clout as the World Trade Organisation has been suggested as one way forward. Rather than detail 
specific organisational configurations, however, I prefer to draw attention to the questions of 'how', rather than the 'who' and 'where': in particular how 'Politics' engages with 'politics'.

For example, some writers suggest fundamental incompatibilities between representative democratic practices and effective sustainability praxis (Bell 2002; see also Dobson 2003). This is due in part to the formers' emphasis on short-termism, and perceived party unity, which arguably stymies openness about the uncertain, incomplete and unpredictable realities of what it means to try and govern, or at least influence. If opinion polls are to be believed to any extent, it seems many of us are crying out for clear and decisive leadership on issues such as climate change (e.g. Climate Institute 2007). But what would leadership that embraces a gestalt-esque approach look like; one that neither appeals to just a dominant narrative (development, often with the word 'sustainable' tacked on the front for good measure) nor rehearses the top/under dog scenario mentioned above? In my own world of possibilities, it would be one where people of public influence start from where they are. That is, we engage with the fact that Politics does not have all the answers; that no one group or person is fully in control; and there is a distinct possibility that we all will not get it right the first (or second and third) time. A tall order I know but researchers are not the only ones who must rise to Le Heron's challenge.

What such a shift might look like is not easy to posit. But I am reminded of a campaign I saw in passing years ago, which has stuck in my head ever since, as it touched gently on some of the contingencies and hidden stories that Engwicht and gestalt allude to. This was a UK antismoking campaign entitled 'Don't give up giving up'. Rather than pictures of damaged lungs or yellow teeth, this campaign engaged with the real challenges of giving up smoking: that is, lapsing being the main one, that can engender feelings of 'well, I've blown it now . . I'm a failure ... might as well have another cigarette, etc'. As someone who had just given up smoking, I remember feeling that the line 'don't give up giving up' was saying it was OK to lapse, it was normal but you can do it: in short, that someone understood what that process had been like. To encourage the same reflexive and 'starting from where we are' approach to such all-encompassing challenges as climate change and sustainability is of course an order of magnitude more challenging - but that does not mean we can not try.

\section{Acknowledgements}

Thanks to all those who organised and attended the Adelaide workshop - it was a fun and informative time. Thank you also to Sandra Davenport for editorial assistance in preparing this article and to Gary Brierley for providing the impetus to write it in the first place. Finally, David Engwicht has been an inspiration, not only to me, but also to many others, and for that we can only be grateful. All remaining errors are of course my own. 


\section{Short Biography}

Kersty Hobson is a Research Fellow in the Department of Human Geography, Research School of Pacific and Asian Studies, the Australian National University, Canberra, Australia. Since receiving her $\mathrm{PhD}$ from University College London in 2001, she has been writing on the issues of sustainable consumption and environmental governance in the UK, Australia, the USA, Singapore and Hong Kong. She has authored papers in these areas for Geoforum, Area, Social and Cultural Geography, Political Geography, and Ethics, Place and Environment; and is on the editorial boards of Geoforum and Sustainability: Science, Practice and Policy.

\section{Notes}

* Correspondence address: Kersty Hobson, Department of Human Geography, Research School of Pacific and Asian Studies, Building 9, H C Coombs Building, Australian National University, Canberra, ACT 0200, Australia. E-mail: kersty.hobson@anu.edu.au.

${ }^{1}$ On 31 March 2007, Sydney residents were asked by the World Wide Fund for Nature in collaboration with the Sydney Morning Herald newspaper to turn off their lights at 7:30 p.m. for $1 \mathrm{hr}$ to observe 'Earth Hour'. The aim was to send out a message that enough people care about the issue, which resulted in (allegedly) 2 million households and businesses participating - which in a city of approximately 4 million people is a healthy show of hands.

\section{References}

Bakker, K., and Bridge, G. (2006). Material worlds? Resource geographies and the 'matter of nature'. Progress in Human Geography 30 (1), pp. 5-27.

Bamberg, S. (2003). How does environmental concern influence specific environmentally related behaviors? A new answer to an old question. Journal of Environmental Psychology 23, pp. 21-32.

Barnett, C., et al. (2005). Consuming ethics: articulating the subjects and spaces of ethical consumption. Antipode 37, pp. 23-45.

Beisser, A. (1970). The paradoxical theory of change. In: Fagan, J. and Shepherd, I. L. (eds) Gestalt therapy now: theory, techniques, and applications. Palo Alto, CA: Science and Behavior Books.

Bell, D. (2002). How can political liberals be environmentalists? Political Studies 50, pp. 703-724.

Bulkeley, H. (2005). Reconfiguring environmental governance: towards a politics of scales and networks. Political Geography 24 (8), pp. 875-902.

Burgess, J. (1999). The genesis of in-depth discussion groups: a response to Liz Bondi. Professional Geographer 51 (3), pp. 458-460.

Burgess, J., Limb, M., and Harrison, C. M. (1988). Exploring environmental values through the medium of small groups: 1. theory and practice. Environment and Planning $A 20$ (3), pp. 309-326.

Burgess, J., et al. (2003). (Un)sustainable consumption. In: Berkhout, F., Leach, M. and Scoones, I. (eds) Negotiating environmental change: new perspectives from social science. Cheltenham, UK: Edward Elgar, pp. 261-292.

Burkitt, I. (2002). Technologies of the self: habitus and capacities. Journal for the Theory of Social Behaviour 32 (2), pp. 219-237.

Butler, J. (1997). Excitable speech: a politics of the performative. New York: Routledge.

Chatterton, P. (2002). 'Be realistic: demand the impossible'. Moving towards 'strong' sustainable development in an old industrial region. Regional Studies 36 (5), pp. 552-561.

Clarke, N., et al. (2007). Globalising the consumer: doing politics in an ethical register. Political Geography 26 (3), pp. 231-249.

Climate Institute. (2007). Climate of the nation. Sydney, Australia: The Climate Institute Australia. 
Cloke, P. (2002). Deliver us from evil? Prospects for living ethically and acting politically in human geography. Progress in Human Geography 26 (5), pp. 587-604.

Darier, E. (1996). Environmental governmentality: the case of Canada's Green Plan. Environmental Politics 5 (4), pp. 585-606.

- (ed.) (1999). Discourses of the environment. Oxford, UK: Blackwell.

de Bono, E. (1999). New thinking for the new millennium. London: Penguin Books.

Dobson, A. (2003). Citizenship and the environment. Oxford, UK: Oxford University Press.

Engwicht, D. (2005). Mental speed bumps: the smarter way to tame traffic. Annandale, Australia: Envirobook.

Ernste, H. (2004). The pragmatism of life in poststructuralist times. Environment and Planning $A$ 36, pp. 437-450.

Flint, C. (2003). Dying for a 'P'? Some questions facing contemporary political geography. Political Geography 22, pp. 617-620.

Flyvbjerg, B. (2001). Making social science matter: why social inquiry fails and how it can succeed again. Cambridge, UK: Cambridge University Press.

Hamilton, C. (2007). Scorcher: the dirty politics of climate change. Melbourne, Australia: Black Inc.

Her Majesty's Government, UK. (2005). Securing the future - delivering UK sustainable development strategy. Norwich, UK: The Stationery Office.

Hinchliffe, S. (1997). Locating risk: energy use, the 'ideal' home and the non-ideal world. Transactions of the Institute of British Geographers 22 (2), pp. 197-209.

Hobson, K. (2001). Sustainable lifestyles: rethinking barriers and behaviour change. In: Cohen, M. J. and Murphy, J. (eds) Exploring sustainable consumption: environmental policy and the social sciences. Oxford, UK: Pergamon Press, pp. 191-213.

- (2003). Thinking habits into action: the role of knowledge and process in questioning household consumption practices. Local Environment 8 (1), pp. 95-112.

- (2006). Bins, bulbs and shower timers: on the 'techno-ethics' of sustainable living. Ethics, Place and Environment 9 (3), pp. 335-354.

Intergovernmental Panel on Climate Change Working Group II. (2007). Climate change 2007: impacts, adaptation and vulnerability. Cambridge, UK: Cambridge University Press.

Krueger, R., and Agyeman, J. (2005). Sustainability schizophrenia or actually existing sustainabilities? Towards a broader understanding of the politics and promise of local sustainability in the USA. Geoforum 36, pp. 410-417.

Le Heron, R. (2006). Towards governing spaces sustainably: reflections in the context of Auckland, New Zealand. Geoforum 37, pp. 441-446.

Lear, J. (2006). Radical hope: ethics in the face of cultural devastation. London: Harvard University Press.

Lynn, W. S. (2003). Act of ethics: a special section on ethics and global activism. Ethics, Place and Environment 6 (1), pp. 43-78.

Massey, D. (2004). Geographies of responsibility. Geografiska Annaler B 86 (1), pp. 5-18.

- (2005). For space. London: Sage Publications.

Mimura, N. (1999). Vulnerability of island countries in the South Pacific to sea level rise and climate change. Climate Research 12, pp. 137-143.

Mitchell, D. (2004). Geography in the age of extremes: a blueprint for a geography of justice. Annals of the Association of American Geographers 94 (4), pp. 764-770.

Najam, A., Huq, S., and Sokona, Y. (2003). Climate negotiations beyond Kyoto: developing countries concerns and interests. Climate Policy 3, pp. 221-231.

O'Neill, O. (1997). Environmental values, anthropocentrism and speciesism. Environmental Values 6, pp. 127-142.

Pain, R. (2003). Social geography: on action-orientated research. Progress in Human Geography 27 (5), pp. 649-657.

Parks, B. C., and Roberts, J. T. (2006). Globalization, vulnerability to climate change, and perceived injustice. Society and Natural Resources 19, pp. 337-355.

Perls, F. (1969). Ego, hunger and aggression: the beginning of gestalt therapy. New York: Random House.

Popke, J. (2006). Geography and ethics: everyday mediations through care and consumption. Progress in Human Geography 30 (4), pp. 504-512.

Princen, T., Maniates, M., and Conca, K. (2002). Confronting consumption. Cambridge, MA: MIT Press. 


\section{Reasons to be cheerful}

Shove, E. (2003). Comfort, cleanliness and convenience: the social organization of normality. Oxford, UK: Berg.

Shove, E., and Walker, G. (2007). CAUTION! Transitions ahead: politics, practice, and sustainable transition management. Environment and Planning A 39, pp. 763-770.

Sibley, D. (2003). Geography and psychoanalysis: tensions and possibilities. Social and Cultural Geography 4 (3), pp. 391-399.

Slocum, R. (2004). Polar bears and energy-efficient lightbulbs: strategies to bring climate change home. Environment and Planning D: Society and Space 22, pp. 413-438.

Starak, Y., Bernet, A., and Maclean, A. (1994). Grounds for gestalt. Christchurch, New Zealand: Foreground Press.

Stern, P. (1992). Psychological dimensions of global environmental change. Annual Review of Psychology 43, pp. 269-302.

The Associated Press. (2007). UN attacks climate change as threat to peace. International Herald Tribune. [online]. Retrieved on 20 April 2007 from http://iht.com/articles/2007/04/17/ news/climate.php

Thomas, D. S. G., and Twyman, C. (2005). Equity and justice in climate change adaptation amongst nature-resource-dependant societies. Global Environmental Change 15, pp. 115-124.

Tol, R. S. J., et al. (2004). Distributional aspects of climate change impacts. Global Environmental Change 14, pp. 259-272.

UK Sustainable Consumption Roundtable. (2006). I will if you will: towards sustainable consumption. [online]. Retrieved on 29 March 2007 from http://www.sd-commission.org.uk/publications/ downloads/I_Will_If_You_Will.pdf

Valentine, G. (1999). A corporeal geography of consumption. Environment and Planning D 17 (3), pp. 329-351.

Varela, F. J. (1999). Ethical know-how: action, wisdom, and cognition. Stamford, CA: Stamford University Press.

Whatmore, S. (2002). Hybrid geographies: natures, cultures, spaces. London: Sage Publications.

- (2006). Materialist returns: practising cultural geography in and for a more-than-human world. Cultural Geographies 13, pp. 600-609. 